\title{
Plasma and tissue levels of digestive regulatory peptides during postnatal development and weaning in the calf *
}

\author{
P Guilloteau 1, I Le Huërou-Luron 1, JA Chayvialle 2, A Mouats 1, \\ C Bernard 2, JC Cuber 2, J Burton 1, A Puigserver 3, R Toullec 1
}

\author{
1 Institut National de la Recherche Agronomique, 65 rue St-Brieuc, 35042 Rennes Cedex; \\ 2 Institut National de la Santé et de la Recherche Médicale, \\ Hôpital Edouard-Herriot, 69374 Lyon Cédex; \\ ${ }^{3}$ Centre National de la Recherche Scientifique, 31 Chemin Joseph-Aiguier, \\ 13402 Marseille Cedex 9, France
}

(Received 13 February 1992; accepted 11 May 1992)

\begin{abstract}
Summary - Changes in the concentrations of cholecystokinin, gastric inhibitory peptide, gastrin, motilin, pancreatic polypeptide, secretin, somatostatin, and vasoactive intestinal peptide in calf plasma and antral, duodenal and/or pancreatic tissues were assessed by radioimmunoassay during postnatal development and after weaning in $\mathbf{5 0}$ male Holstein-Friesian calves (randomly distributed into 10 groups of 5 animals each). The calves in the first group were killed at birth while those in 6 other groups were colostrum-fed for 2 days and then milk-fed until $7,28,56,70$ or 119 days of age. Those in the remaining 3 groups were given the same diets until day 28 , were then weaned between day $29-56$, and slaughtered on days 56,70 or 119 . In milk-fed animals, changes in plasma and tissue concentrations of almost all digestive regulatory peptides were observed during the 1 st month of postnatal life, especially at day 2. Weaning was accompanied by variations in the plasma concentrations of somatostatin, secretin, gastrin, pancreatic polypeptide and gastric inhibitory peptide but not by any apparent change in peptide tissue concentrations (except VIP in the duodenum). Thus, the variations in tissue concentrations are primarily age-related, while plasma concentrations were modified by age and weaning.
\end{abstract}

digestive regulatory peptide / calf / development / milk feeding / weaning

Résumé - Taux plasmatiques et tissulaires de quelques peptides régulateurs digestifs au cours du développement postnatal et du sevrage chez le veau. Les variations de concentrations de cholécystokinine, peptide inhibiteur gastrique, gastrine, motiline, polypeptide pancréatique, sécrétine, somatostatine et peptide intestinal vaso-actif ont été étudiées aux niveaux plasmatique et tissulaires (antrum, duodénum etlou pancréas) au cours du développement postnatal et du sevrage chez le veau (10 groupes de 5 veaux). Les veaux du premier groupe ont été abattus à la naissance tandis que les animaux de 6 autres groupes ont reçu du colostrum pendant $2 j$, puis du lait de

* A preliminary report on some of this work was presented at the 4th International Symposium on VIP and Related Peptides, Stockholm, Sweden, September 1989 
remplacement jusqu'aux âges de 7,28,56,70 ou $119 \mathrm{j}$. Ceux des 3 derniers groupes ont été alimentés avec les mêmes régimes jusqu'à $28 j$, sevrés entre le $29^{\circ}$ et le $56^{\circ} j$ et abattus à 56,70 ou $119 \mathrm{j}$. Chez les veaux préruminants, des variations significatives des taux circulants et tissulaires de la plupart des peptides étudiés ont été observées pendant le premier mois de vie postnatale, en particulier à l'âge de $2 \mathrm{j}$. Le sevrage s'est accompagné de modifications des concentrations plasmatiques de la somatostatine, de la sécrétine, de la gastrine, du polypeptide pancréatique et du peptide inhibiteur gastrique. Au niveau des tissus, aucun peptide n'a présenté de variation significative, à l'exception du VIP dans le duodénum. Ainsi, les concentrations tissulaires varient principalement avec l'âge, tandis que les concentrations plasmatiques évoluent avec l'âge et lors du sevrage.

\section{peptide régulateur digestif / développement / veau / allaitement / sevrage}

\section{INTRODUCTION}

Calves are usually given colostrum during the first 2 days of life before going onto a whole milk or a milk-substitute diet. Owing to the closure of the oesophageal groove, liquid food by-passes the forestomachs and is digested as in monogastric animals. Preruminant calves are therefore exclusively milk-fed and are then usually maintained at this stage up to the age of 4-6 months for veal production. When dairy breed calves are reared for herd replacement or beef production, they are rapidly offered solid food ad libitum and decreasing amounts of milk, and weaned at the age of 6-10 weeks. In the latter case, solid food enters the rumen, and subsequent development of the forestomachs is observed together with an increasing amount of microbial digestion (Thivend et al, 1980). At the end of the weaning period, calves are no longer considered to be preruminants but ruminants. Studies dealing with the biochemical and physiological changes accompanying this important anatomical modification of the gut are rather scarce (Ruckebush et al, 1983). Little information is available on the hormonal factors involved in the response of the digestive tract to dietary manipulations in the calf (Titchen, 1986). The present study was undertaken to determine the plasma and tissue levels of 8 gut regulatory peptides at birth, and to examine the develop- mental changes occurring when the calves were either maintained at the preruminant stage or weaned.

\section{MATERIALS AND METHODS}

\section{Animals and feeding}

Fifty newborn Holstein-Friesian male calves obtained at birth from the herd at the Station de Recherches sur la Vache Laitière (Institut National de la Recherche Agronomique, 35590 Saint-Gilles, France) were randomly distributed into 10 groups of 5 animals each (table I). The calves in the 1st group were slaughtered at birth prior to any food ingestion, while those in the 2nd group were given 2 colostrum meals $(25 \mathrm{~g} /$ $\mathrm{kg}$ liveweight/meal) during the first day of life and killed the following day. The animals in the remaining 8 groups were fed colostrum during the first 2 days of life, and then a milk substitute based on spray-dried skim milk and tallow $(25 \%$ crude protein, $22 \%$ fat, $43 \%$ lactose, $3 \%$ starch and $7 \%$ ash on a dry matter (DM) basis) for various periods of time. Milk was given twice daily at $8.30 \mathrm{am}$ and $4.30 \mathrm{pm}$. The calves in the $3 \mathrm{rd}$ and 4th groups were slaughtered at 7 and 28 days of age, respectively, while those in the 5th, 6 th and 7 th groups (ie preruminant calves) continued to be exclusively milk-fed until slaughter on days 56, 70 and 119 , respectively. The amount of DM fed was progressively increased on weight basis, from 370 to $2680 \mathrm{~g} /$ day over the feeding period (7-118 days). From day 29 onwards, the calves in the 8th, 9th and 10th groups were given water, hay and a commercial 
Table l. Liveweight gain, empty liveweight and dry matter intake by preruminant and ruminant calves between birth and slaughter. Means $\pm \mathrm{SEM} ; n=5$.

\begin{tabular}{|c|c|c|c|c|c|c|c|c|c|c|}
\hline \multirow{2}{*}{$\begin{array}{l}\text { Stage } \\
\text { Group }\end{array}$} & \multicolumn{7}{|c|}{ Preruminant } & \multicolumn{3}{|c|}{ Ruminant } \\
\hline & 1 & 2 & 3 & 4 & 5 & 6 & 7 & 8 & 9 & 10 \\
\hline $\begin{array}{l}\text { Age } \\
\text { at slaughter (d) }\end{array}$ & 0 & 2 & 7 & 28 & 56 & 70 & 119 & 56 & 70 & 119 \\
\hline $\begin{array}{l}\text { Liveweight } \\
\text { gain }(g / d)\end{array}$ & - & $\begin{array}{l}-210 \\
\pm 111\end{array}$ & $\begin{array}{l}-343 \\
\pm 59\end{array}$ & $\begin{array}{r}400 \\
\pm 18\end{array}$ & $\begin{array}{l}711 \\
\pm 16\end{array}$ & $\begin{array}{r}843 \\
\pm 23\end{array}$ & $\begin{array}{l}1081 \\
\pm 24\end{array}$ & $\begin{array}{r}446 \\
\pm 28\end{array}$ & $\begin{array}{r}594 \\
\pm 15\end{array}$ & $\begin{array}{r}766 \\
\pm 16\end{array}$ \\
\hline $\begin{array}{l}\text { Empty } \\
\text { liveweight (kg) }\end{array}$ & $\begin{array}{r}45.8 \\
\pm 1.1\end{array}$ & $\begin{array}{l}33.8 \\
\pm 0.7\end{array}$ & $\begin{array}{r}42.4 \\
\pm 2.1\end{array}$ & $\begin{array}{r}51.5 \\
\pm 1.5\end{array}$ & $\begin{array}{r}82.4 \\
\pm 1.4\end{array}$ & $\begin{array}{r}98.5 \\
\pm 2.0\end{array}$ & $\begin{array}{l}172.3 \\
\pm 1.8\end{array}$ & $\begin{array}{l}65.6 \\
\pm 1.4\end{array}$ & $\begin{array}{r}74.5 \\
\pm 1.2\end{array}$ & $\begin{array}{l}117.6 \\
\pm 1.3\end{array}$ \\
\hline $\begin{array}{l}\text { Dry matter } \\
\text { intake }(g / d)^{b}\end{array}$ & - & $\begin{array}{l}454^{c} \\
\pm 11\end{array}$ & $\begin{array}{l}371 \\
\pm 11\end{array}$ & $\begin{array}{r}1013 \\
\pm 14\end{array}$ & $\begin{array}{l}1585 \\
\pm 24\end{array}$ & $\begin{array}{l}1842 \\
\pm 19\end{array}$ & $\begin{array}{l}2681 \\
\pm 36\end{array}$ & $\begin{array}{l}1205 \\
\pm 77\end{array}$ & $\begin{array}{c}2212 \\
\pm 53\end{array}$ & $\begin{array}{c}3827 \\
\pm 91\end{array}$ \\
\hline
\end{tabular}

a Liveweight minus weight weight of digestive contents; ${ }^{b}$ dry matter intake was that during the week prior to slaughter ( ${ }^{c}$ between birth and 2 days of age).

starter concentrate ad libitum. On a DM basis, the hay contained $14 \%$ crude protein, $3 \%$ fat, $31 \%$ cellulose and $9 \%$ ash, while the concentrate contained $23 \%$ crude protein, $2 \%$ fat, $60 \%$ starch, $5 \%$ cellulose and $10 \%$ ash. The amount of milksubstitute was gradually reduced to nil between days 29 and 56 , ie from 950 to $710,475,235$ and $0 \mathrm{~g}$ DM/day between days 29-35, 36-42, 43-49, 50-56 and onwards, respectively. The ruminant calves in the last 3 groups were killed at the end of the weaning period, and 14 and 63 days later (ie at 56, 70 and 119 days of age), respectively, as were the preruminant calves in the 5th, 6th and 7th groups. The final composition of the ingested rations is given in table 11 .

\section{Sampling and analysis}

Calves were slaughtered $16-17 \mathrm{~h}$ after their last meal, except for those in the first group which were killed during the first hour after birth, before any milk ingestion. Blood was collected on heparin $(500 \mathrm{IU} / \mathrm{ml}$ blood) and aprotinin (10 $000 \mathrm{lU} / \mathrm{ml}$ blood) from an external jugular vein either the morning before slaughter, prior to any food intake, or just before slaughter in the case of the first group. Plasma samples were stored at $-45^{\circ} \mathrm{C}$. Immediately afterwards the animals were killed in the slaughterhouse, the whole digestive tract was rapidly removed and placed in a plastic bag covered with ice. Within $1 \mathrm{~h}$ of death, tissue samples of about $1 \mathrm{~cm}^{2}$ were stamped out from the greater curvature of the antrum, the left lobe of the pancreas and the duodenum $5 \mathrm{~cm}$ from the pylorus. Samples were immediately frozen in liquid nitrogen and stored at $-45^{\circ} \mathrm{C}$.

Tissue samples maintained on dry ice were cut out in small pieces and placed in tubes containing 0.8 or $1.6 \mathrm{ml}$ of distilled water, depending on the amount of fresh tissue (lower or higher than $500 \mathrm{mg}$, respectively), at $90^{\circ} \mathrm{C}$ for $10 \mathrm{~min}$, then homogenized with a glass tissue grinder (Kontes) sequentially in 2.4 and $1.6 \mathrm{ml}$ of $50 \mathrm{mM}$ potassium phosphate buffer $(\mathrm{pH}$ 6.0) containing $100 \mathrm{mM}$ sodium chloride, $5 \%$ decomplemented pig plasma and $50 \mathrm{U}$ of aprotinin per $\mathrm{ml}$, respectively. The suspension was transferred using a rinsing volume of $2.4 \mathrm{ml}$ of buffer, and centrifuged at $2000 \mathrm{~g}$ for $10 \mathrm{~min}$. The resulting pellet was resuspended in $0.8 \mathrm{ml}$ of $0.5 \mathrm{M}$ acetic acid, stirred at $4^{\circ} \mathrm{C}$ for $2 \mathrm{~h}$, neutralized with $0.4 \mathrm{ml}$ of $2 \mathrm{M}$ sodium hybroxide and recentrifuged. The combined supernatants were stored at $-20^{\circ} \mathrm{C}$ in 3 equal volumes.

The immunoreactive somatostatin concentration levels were determined in antral, duodenal and pancreatic tissue extracts, while gastrin was assayed only in antral and duodenal extracts, pancreatic polypeptide (PP) in pancreatic ex- 
Table II. Dietary components ingested ( $\mathrm{g} . \mathrm{kg}$ empty liveweight ${ }^{-1} \cdot \mathrm{d}^{-1}$ ) by preruminant and ruminant calves during the week prior to slaughter. Means $\pm \mathrm{SEM} ; n=5$.

\begin{tabular}{lccccccccccc}
\hline Stage & \multicolumn{1}{c}{ Preruminant } & \multicolumn{9}{c}{ Ruminant } \\
\hline Group & 1 & 2 & 3 & 4 & 5 & 6 & 7 & 8 & 9 & 10 \\
Age at & 0 & 2 & 7 & 28 & 56 & 70 & 119 & 56 & 70 & 119 \\
slaughter (d) & & & & & & & & & & \\
Protein & - & 8.0 & 2.2 & 4.9 & 4.8 & 4.6 & 3.8 & 3.9 & 5.8 & 6.4 \\
& & \pm 0.0 & \pm 0.1 & \pm 0.3 & \pm 0.2 & \pm 0.2 & \pm 0.1 & \pm 0.5 & \pm 0.2 & \pm 0.3 \\
Fat & - & 2.5 & 2.0 & 4.3 & 4.2 & 4.1 & 3.4 & 0.9 & 0.2 & 0.2 \\
& & \pm 0.0 & \pm 0.1 & \pm 0.9 & \pm 0.2 & \pm 0.2 & \pm 0.2 & \pm 0.1 & \pm 0.1 & \pm 0.1 \\
Lactose & - & 1.5 & 3.9 & 8.7 & 8.3 & 8.2 & 6.8 & 1.7 & - & - \\
& & \pm 0.0 & \pm 0.2 & \pm 0.5 & \pm 0.3 & \pm 0.3 & \pm 0.2 & \pm 0.1 & & \\
Starch & - & - & 0.3 & 0.6 & 0.6 & 0.6 & 0.5 & 7.2 & 13.5 & 14.7 \\
& & & \pm 0.1 & \pm 0.1 & \pm 0.1 & \pm 0.1 & \pm 0.1 & \pm 1.3 & \pm 0.5 & \pm 0.7 \\
Cellulose & - & - & - & - & - & - & - & 1.7 & 3.5 & 4.1 \\
& & & & & & & & \pm 0.3 & \pm 0.2 & \pm 0.2 \\
\hline
\end{tabular}

tracts, and secretin, motilin, cholecystokinin (CCK), vasoactive intestinal peptide (VIP) and gastric inhibitory polypeptide (GIP) in duodenal extracts. The plasma concentrations of these 8 immunoreactive peptides were also determined. The radioimmunoassays used throughout this study have previously been described for gastrin (Chayvialle et al, 1978), CCK, GIP and PP (Miazza et al, 1985), secretin (Pelletier et al, 1978), somatostatin and VIP (Chayvialle et al, 1980), and motilin (Cuber et al, 1985). Results are expressed as pg equivalent standard preparation per $\mathrm{ml}$ of plasma, or as $\mathrm{ng}$ per $\mathrm{g}$ wet weight. Standard peptides were human gastrin I, bovine PP, porcine CCK 33, porcine secretin, porcine GIP, porcine motilin, porcine VIP, and ovine somatostatin.

\section{Statistical analysis}

Variance analysis was used to assess the effects of age in either preruminant or ruminant group, and Newman-Keuls, test to classify the means. The significance of the differences between preruminant and ruminant calves at 56 , 70 and 119 days of age was determined using Mann-Whitney's test. Correlation coefficients were calculated to determine the relationships between regulatory peptide levels. Differences were taken to be significant at $P \leq 0.05$.

\section{RESULTS}

\section{Growth and food intake}

Liveweight gain was negative during the first week of life but increased thereafter up to mean cumulated values of $1081 \mathrm{~g} /$ day and $766 \mathrm{~g} /$ day on day 119 in preruminant and ruminant calves, respectively (table 1). These results are similar to those obtained under practical breeding conditions with intensively fed Holstein-Friesian calves (INRA, 1978).

\section{Plasma peptide concentrations}

The $0-119$ day profiles in preruminant calves appear to be segregated into 3 different types (fig 1). The 1 st type was that 

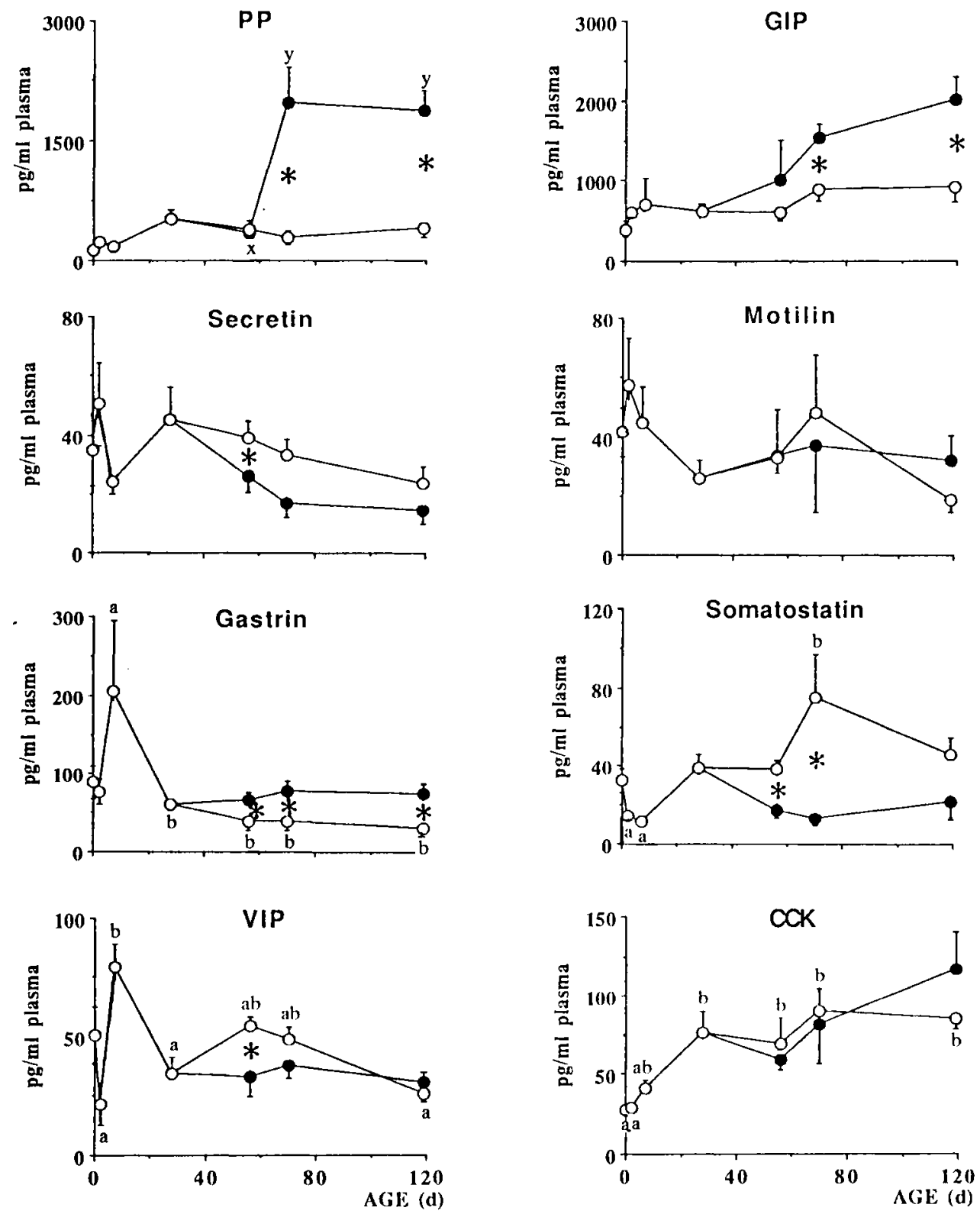

Fig 1. Changes in calf plasma concentrations $(\mathrm{pg} / \mathrm{ml}$ plasma) of 8 digestive regulatory peptides with age and at weaning (means \pm SEM, $n=5$ ) (O preruminants; ruminants). $a, b, c$ and $x, y$ : within preruminant and ruminant groups, respectively, only values bearing different letters are significantly different $(P \leq 0.05)$. *: significant difference between preruminants and ruminants $(P \leq 0.05)$. 
of PP, GIP, secretin and motilin; they did not significantly vary from birth level. The 2nd subgroup included peptides with large variations between day 0 and 7 . Plasma gastrin approximately doubled from day 2 to 7 , then declined to values similar to those found at birth, but only this last change was significant. Plasma VIP increased between day 2 and 7 and decreased to the 2-day value thereafter. The last type was that of CCK and somatostatin. Plasma CCK showed a significant increase above birth value at all times from day 28 to 119 and plasma somatostatin was transiently increased 5.4-fold between day 7 and 70 . Only CCK and PP bore a significant positive correlation $(r=0.46)$.

Weaning resulted in decreased values for somatostatin and, to a lesser extent, for secretin and VIP (fig 1). In contrast, the plasma concentrations were higher for gastrin, GIP and PP in weaned calves than in milk-fed animals. CCK and motilin exhibited no major alteration. Again, the only significant correlation was between CCK and PP $(r=0.57)$.

\section{Tissue peptide concentrations}

In preruminants, significant variations occurred for each of the 7 peptides tested in the duodenum (fig 2). Gastrin, secretin and somatostatin showed a $80-100 \%$ increase above birth value at day 2 , followed by a return to birth level at day 7 . Concentrations did not change thereafter. An injtial increase, though less marked, was also observed in the case of GIP and CCK. All 3 declined thereafter, abruptly for GIP and motilin, more slowly for CCK. Duodenal VIP concentration showed a peak at day 70 (fig 2). In the antrum and pancreas, no significant changes were evidenced. However, in the antrum, the pattern of tissue gastrin concentrations re- sembled the duodenal pattern (fig 3); it increased by almost $200 \%$ at days 2 and 7 , then declined to values similar to those at birth. Fairly similar profiles were recorded for somatostatin in antrum and pancreas, with a moderate increase above birth value at day 2, a subsequent decrease until day 28 , and the return to birth level thereafter (fig 3). Pancreatic PP concentration was maximal between birth and day 7 , then slowly decreased until day 119 (fig 3).

In contrast to the effect on plasma levels, weaning had no clear effect on tissue peptide concentrations (figs 2,3 ) except that it suppressed the peak of duodenal VIP concentration that was observed in preruminants at day 70 .

\section{DISCUSSION}

Very few studies have been devoted to digestive regulatory peptides in the developing calf, although weaning is known to result in particularly striking changes in the digestive processes (Guilloteau et al, 1985, 1986; Le Huërou et al, 1990, 1992) that may be partly dependent on hormonal factors. The present work was designed to allow for distinct analysis of age- and weaning-related variations of 8 peptides, ie 6 established or putative hormones, one known as paracrine messenger (somatostatin), and one typical neuropeptide (VIP). In addition to the gastric antrum and pancreas, the duodenum was selected for study because the density of peptideproducing structures is high (Bloom and Polak, 1978; Sjölund et al, 1983).

In agreement with our previous results (Guilloteau et al, 1984, 1985), plasma peptide concentrations were easily measurable at birth. Similar observations were made on gastrin and PP in the lamb (Lichtenberger et al, 1981; Shulkes and Hardy, 1982) and for gastrin, secretin, somatosta- 

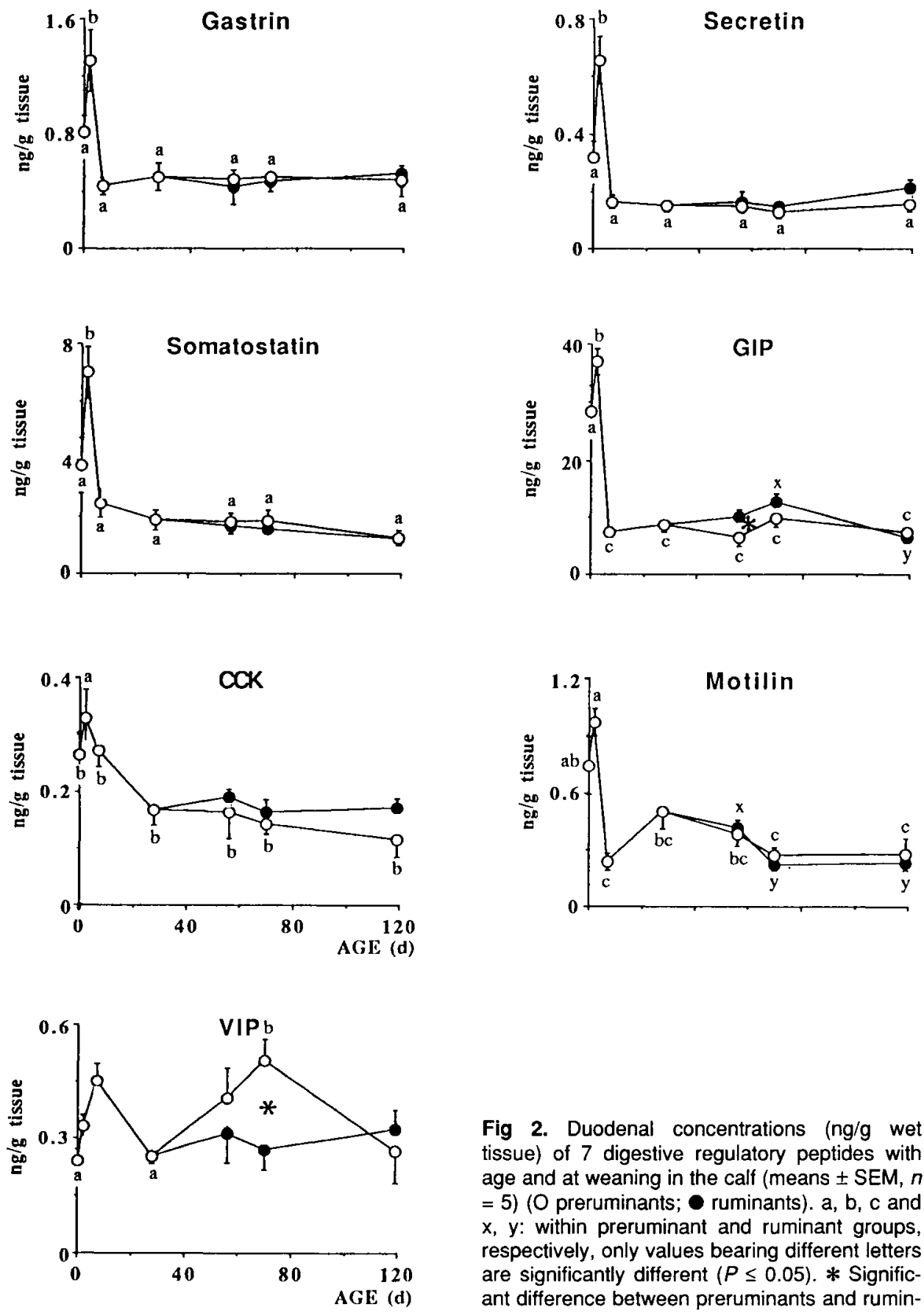

Fig 2. Duodenal concentrations (ng/g wet tissue) of 7 digestive regulatory peptides with age and at weaning in the calf (means \pm SEM, $n$ $=5$ ) (O preruminants; ruminants). a, b, c and $x, y$ : within preruminant and ruminant groups, respectively, only values bearing different letters are significantly different $(P \leq 0.05)$. * Significant difference between preruminants and rumin- 

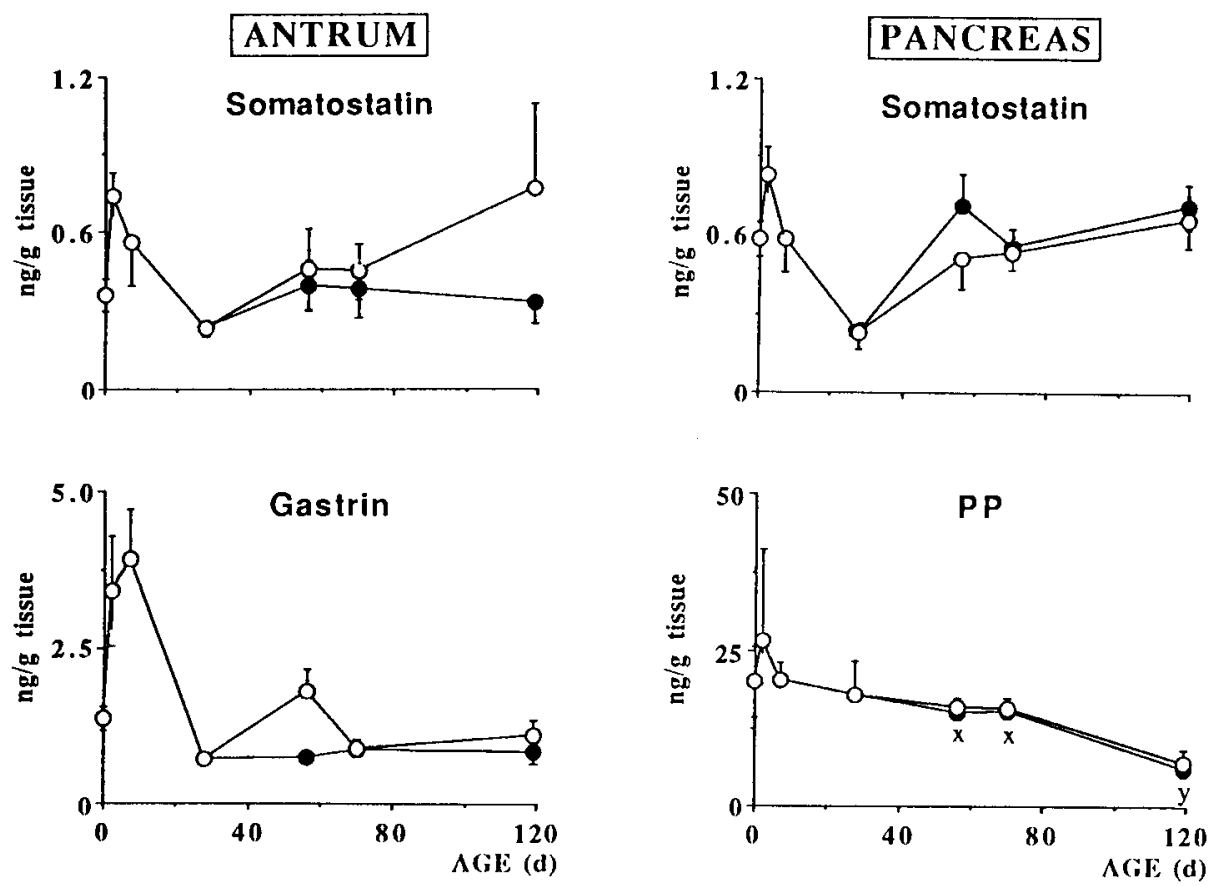

Fig 3. Changes in the antral concentrations of somatostatin and gastrin and in the pancreatic concentrations of somatostatin and PP with age and at weaning in the calf (means $\pm S E M ; n=5)(O$ preruminants; ruminants). $x, y$ : within the ruminant group, only values bearing different letters are significantly different $(P \leq 0.05)$.

tin, motilin, PP and GIP in various species including man (Rodgers et al, 1978; Cranwell and Hansky, 1980; Lucas et al, 1982; Thompson et al, 1987). Caution is, however, required in interpreting those and the present results, because immunoreactivity is not synonymous with structural identity. In particular, gastrin and CCK can be secreted as incompletely processed compounds, eg biologically inactive glycineextended forms. The contribution of such forms to the plasma immunoreactivity has not been assessed here.

There was no consistent pattern of agerelated variation in plasma concentrations in preruminant calves, suggesting that the nature of nutrient ingested is not the predominant tuning factor for basal release of digestive peptides. Except for the steady increase of plasma CCK, the most systematized variations were those of gastrin and somatostatin, which mirrored each other. This suggests some interaction between somatostatin and $G$ cells (Minaire, 1991). Another intriguing observation was the large rise of plasma VIP at day 7. Upon its release from intestinal stores, VIP is known to be cleared at first hepatic transit (Khalil et al, 1975; Guilloteau et al, unpublished data).

The present profiles of tissue peptide concentrations were fairly similar to those 
reported for somatostatin in unweaned rats (Koshimizu, 1983), and for secretin (Paquette et al, 1982; Ichihara et al, 1983) GIP (Gespach et al, 1979) and CCK (Noyer et al, 1980; Brand, 1982; Ichihara et al, 1983) in several non-ruminant species. Our results on antral gastrin differed from the steady concentrations recorded from $45 \mathrm{~h}$ postpartum in the lamb (Reynolds et al, 1991) and in the milk-fed rat from 0-18 days (Lichtenberger and Johnson, 1974; Takeuchi et al, 1981). Another discrepant result here was the 70-day peak of duodenal VIP, while other groups reported either a steady increase in rat (Laburthe et al, 1978; Ichihara et al, 1983) or no change in the guinea pig (Huang et al, 1986). To our knowledge, the present results are the first to be reported on the postnatal evolution of duodenal motilin and of pancreatic PP.

Five of the 7 peptides tested in the duodenum showed an increase of tissue concentration on day 2 , a variation that could be recognized with the present sampling schedule. This initial increase was followed by an abrupt decrease by day 7 . No explanation is available at the moment for these variations. Possibly the synthesis and/or processing of peptides was enhanced by the first meals, a hypothesis to be tested via parental nutrition in the newborn. An alternative explanation would be the decay of some inhibitory factor(s) of maternal origin. Additional research is required to assess whether the increase of tissue concentration results from transcriptional or postranscriptional events.

Weaning resulted in no clear variation of tissue peptide concentrations, except for the disappearance of the peak of duodenal VIP concentration that was recorded at day 70 in preruminants. Similar results were obtained in rats for intestinal gastrin (Lichtenberger and Johnson, 1974) and pancreatic and duodenal somatostatin
(Ghirlanda et al, 1978). In contrast, several groups reported that weaning exerted significant effects. Results gathered in rats included an increase in antral gastrin (Lichtenberger and Johnson, 1974; Takeuchi et al, 1981), antral somatostatin (Koshimizu, 1983), duodenal VIP (Laburthe et al, 1978; Ichihara et al, 1983; Huang et al, 1986), and a decrease in duodenal GIP (Gespach et al, 1979). On the other hand: i), duodenal CCK was reported to be stable (Brand, 1982; Huang et al, 1986) or to decrease slightly (Noyer et al, 1980; Ichihara et al, 1983) and ii), duodenal secretin concentration remained steady (Paquette et al, 1982; Huang et al, 1986), or increased (Ichihara et al, 1983). These heterogenous results cannot be reconciled with our data. Altogether, they suggest some speciesrelated variability of the effects of weaning on tissue peptide concentrations. Unless they were too transient to be picked up through our sampling schedule, these effects appear to be very limited in the calf.

In contrast, weaning definitely altered the plasma concentration of several peptides. A gastrin rise was observed in 2025-day-old rats (Takeuchi et al, 1981), but not in 21-42-day-old piglets (Cranwell and Hansky, 1980). The most likely explanation for the postweaning rise of plasma gastrin may be that the stomach was never empty in weaned calves. Gastrin release is indeed triggered by the presence of (protein) nutrients in the lumen, and by antrum (Bergegardh and Olbe, 1975; Debas et al, 1975) and fundus (Grotzinger et al, 1977) distension. Moreover, $\mathrm{G}$ cells may be more responsive to solid than to liquid food (Hirschowitz, 1983). In milk-fed calves, the plasma concentrations were higher $1 \mathrm{~h}$ after the meal than during fasting for gastrin, CCK, and GIP, and were lower for secretin; in contrast, no variation appeared for VIP, somatostatin and PP (Guilloteau et al, 1986). Therefore, the persistent flow of nu- 
trients in the lumen could similarly account for the enhanced release of GIP and gastrin, and for the decreased release of secretin in weaned calves. However, their effects were more pronounced than those reported with the meal in preruminant calves for PP, somatostatin and VIP, but less for CCK. The rise in PP was clearly greater than that in gastrin and GIP, especially during the early postweaning period. $\mathrm{PP}$ release is strongly dependent on parasympathetic control (Bloom et al, 1978). Thus, chemical mucosal stimulation by nutrients may not be the sole factor for changed peptide release in weaned animals.

On the whole, the present observations provide distinct overviews of age- and weaning-related changes in several digestive regulatory peptides. The variations in tissue concentrations are primarily agerelated, since they were influenced by weaning only for GIP and VIP; in contrast, most plasma concentrations were modified by age and weaning. Much remains to be done before the potential links between regulatory digestive peptide profiles and the development of digestive functions can be elucidated, especially with regard to gastric and pancreatic secretions (Guilloteau et al, 1985, 1986; Le Huërou et al, 1990). Nevertheless, pancreatic receptors to the VIP and secretin family and regulating cAMP generation have recently been evidenced in newborn calves, in 28 and 119 day-old preruminant calves and 119 day-old ruminant calves (Le Meuth et al, 1991). During the same period, the expression of the genes involved in the synthesis of many pancreatic enzymes appeared to be regulated by both pretranslational and translational controls in the preruminant calf, but mainly by pretranslational controls in the ruminant (Le Huërou et al, 1990).

\section{ACKNOWLEDGMENTS}

Our thanks are due to $\mathrm{J}$ Quillet for collecting the bibliographical information and to $M$ Beaufils, $S$ Boussion, M Connan, M Formal and PM Lucas for technical assistance. The financial support of the European Community (No $4+11 \mathrm{~A}$ ) is gratefully acknowledged.

\section{REFERENCES}

Bergegardh S, Olbe L (1975) Gastric acid response to antrum distension in man. Scand $J$ Gastroenterol 10, 171-176

Bloom SR, Polak JM (1978) Gut hormones overview. In: Gut Hormones (Bloom SR, Polak $\mathrm{JM}$, eds) Churchill Livingstone, Edinburgh, 118

Bloom SR, Edwards AV, Hardy RN (1978) The role of the autonomic nervous system in the control of glucagon, insulin and pancreatic polypeptide release from the pancreas. J Physiol 280, 9-23

Brand SJ (1982) The postnatal development of cholecystokinin-like activity in the brain and small intestine of the rat. J Physio/ 326, 425433

Chayvialle JA, Descos F, Martin A, Barbe C, Partensky C (1978) Somatostatin in mucosa of stomach and duodenum in gastroduodenal disease. Gastroenterology 75, 13-19

Chayvialle JA, Miyata M, Rayford PL, Thompson JC (1980) Effects of test-meal, intragastric nutrients and intraduodenal bile on plasma concentrations of immunoreactive somatostatin and vasoactive intestinal peptide in dogs. Gastroenterology 79, 844-852

Cranwell PD, Hansky J (1980) Serum gastrin in newborn, suckling and weaned pigs. Res $V e t$ Sci 29, 85-88

Cuber JC, Bernard C, Laplace JP, Chayvialle JA (1985) Comparative assessment of secretin and motilin responses to graded duodenal acidification in anesthetized pigs. Digestion $32,35-41$

Debas HT, Walsh JH, Grossman Ml (1975) Mechanism of release of antral gastrin. In: Gastrointestinal Hormones (Thompson JC, 
ed), The University of Texas Press, Austin, TX, 425-435

Gespach C, Bataille D, Jarousse C, Rosselin C (1979) Ontogeny and distribution of immunoreactive gastric inhibitory polypeptide (IRGIP) in rat small intestine. Acta Endocrinol (Copenh) 90, 307-316

Ghirlanda G, Bataille D, Dubois MP, Rosselin G (1978) Variations of the somatostatin content of gut, pancreas, and brain in the developing rat. Metabolism 27, 1167-1170

Grotginzer U, Bergegardh S, Olbe L (1977) Effect of fundic distension on gastric acid secretion in man. Gut 18, 105-111

Guilloteau P, Chayvialle JA, Toullec R, Grongnet JF, Dardillat C (1984) Early life pattern of plasma secretin level in calves. Can J Anim Sci64 (suppl) 100-101

Guilloteau P, Chayvialle JA, Toullec R, Grongnet JF, Dardillat C (1985) Evolution des taux circulants de gastrine chez le veau. Reprod Nutr Dev 25, 780

Guilloteau P, Corring T, Chayvialle JA, Bernard C, Sissons JW, Toullec R (1986) Effect of soya protein on digestive enzymes, gut hormone and anti-soya antibody plasma level in the preruminant calf. Reprod Nutr Dev 26, 717-728

Hirschowitz BI (1983) Gastrin release in fistula dogs with solid compared to nutrient and non-nutrient liquid meals. Dig Dis Sci 28 , 705-711

Huang CG, Eng J, Yallow S (1986) Ontogeny of immunoreactive cholecystokinin, vasoactive intestinal peptide and secretin in guinea pig brain and gut. Endocrinology 119, 1096-1101

lchihara K, Eng J, Yallow RS (1983) Ontogeny of immunoreactive CCK, VIP and secretin in rat brain and gut. Biochem Biophys Res Commun 112, 891-898

INRA (1978) Alimentation des Ruminants. INRA, Versailles

Khalil T, Alinder G, Rayford PL (1975) Vasoactive intestinal peptide. In: Gastrointestinal Hormones (Thompson JC, ed) The University of Texas Press, Austin, TX, 260-272

Koshimizu T (1983) The development of pancreatic and gastrointestinal somatostatin-like immunoreactivity and its relationships to feeding in neonatal rats. Endocrinology 112, 911-916
Laburthe M, Bataille D, Rosselin G (1978) Vasoactive intestinal peptide (VIP): variation of the jejuno-ileal content in the developing rat as measured by radio-receptor assay. Acta Endocrinol (Copenh) 84, 588-599

Le Huërou I, Wicker $C$, Guilloteau P, Toullec R, Puigserver A (1990) Specific regulation of the gene expression of some pancreatic enzymes during postnatal development and weaning in the calf. Biochim Biophys Acta 1048, 257-264

Le Huërou I, Guilloteau P, Wicker C, Mouats A, Chayvialle JA, Bernard C, Burton J, Toullec R, Puigserver A (1992) Activity distribution of seven digestive enzymes along small intestine in calves during development and weaning. Dig Dis Sci 37, 40-46

Le Meuth V, Farjaudon N, Bawab W, Chastre E, Rosselin G, Guilloteau P, Gespach C (1991) Characterization of binding sites for VIPrelated peptides and activation of adenylate cyclase in developing pancreas. Am J Physiol 260 , G265-G274

Lichtenberger LM, Johnson LR (1974) Gastrin in the ontogenic development of the small intestine. Am J Physiol 227, 390-395

Lichtenberger LM, Crandell SC, Palma PA, Morriss $\mathrm{FH}$ (1981) Ontogeny of tissue and serum gastrin concentrations in fetal and neonatal sheep. Am J Physiol 241, G235-G241

Lucas A, Bloom SR, Aynsley-Green A (1982) Postnatal surges in plasma gut hormones in term and preterm infants. Biol Neonate 41, 63-67

Miazza B, Palma R, La Chance JR, Chayvialle JA, Jomard PP, Modigliani R (1985) Jejunal secretory effect of intraduodenal food in man: a comparison of mixed nutrients, proteins, lipids and carbohydrates. Gastroenterology 88 , 1215-1222

Minaire YP (1991) Acidité gastrique et sécrétion de gastrine : mécanismes cellulaires. Gastroenterol Clin Biol 15, 73C-79C

Noyer M, Diem Bui N, Deschodt-Lanckman M, Robberrecht P, Woussen MC, Christophe J (1980) Postnatal development of the cholecystokinin-gastrin family of peptides in the brain and the gut of rat. Live Sci 27, 21972203

Paquette TL, Shuiman DF, Alpers DH, Jaffe BM (1982) Postnatal development of intestinal 
secretin in rats and guinea pigs. Am $J$ Physiol 6, G511-G517

Pelletier MJ, Chayvialle JA, Minaire Y (1978) Uneven and transitory secretin release after a liquid test-meal. Gastroenterology 75, 1124-1132

Reynolds GW, Simpson HV, Carr DH, Mc Leay LM (1991) Gastrin: its molecular forms in secretion in sheep. In: Physiological Aspects of Digestion and Metabolism in Ruminants (Tsuda T, Sasaki Y, Kawashima R, eds) Academic Press, London, 63-88

Rodgers BM, Dix PM, Talbert JL, Mc Guigan JE (1978) Fasting and postprandial gastrin in normal human neonates. J Pediatr Surg 13, 13-16

Ruckebusch Y, Dardillat C, Guilloteau P (1983) Development of digestive functions in the newborn ruminant. Ann Rech Vet 14, 360374

Shulkes A, Hardy KJ (1982) Ontogeny of circulating gastrin and pancreatic polypeptide in the foetal sheep. Acta Endocrinol 100, 565-572
Sjölund K, Sanden G, Hakanson R, Sundler F (1983) Endocrine cells in human intestine: an immunocytochemical study. Gastroenterology $85,1120-1130$

Takeuchi K, Peitsch W, Johnson LR (1981) Mucosal gastrin receptor. V. Development in newborn rats. Am J Physiol 240, G163-G169

Thivend P, Toullec R, Guilloteau P (1980) Digestive adaptation in the preruminant. In: $\mathrm{Di}$ gestive Physiology and Metabolism in Ruminants (Ruckebusch $Y$, Thivend $P$, eds) MTP Press, Lancaster, 561-586

Thompson JC, Greeley GH, Rayford PL, Townsend CM (1987) Gastrointestinal Endocrinology (Thompson JC, Greeley GH, Rayford PL, Townsend CM, eds) McGraw-Hill, New York, 194-360

Titchen DA (1986) Gastrointestinal peptide hormone distribution, release, and action in ruminant. In: Control of Digestion and Metabolism in Ruminants (Milligan HLP, Grovum WL, Dobson A, eds) Reston Book, New Jersey, $227-248$ 